\title{
無人運転技術を用いた車両共有システムの 導入に伴う環境影響に関する分析
}

\author{
ENVIRONMENTAL IMPACT BY COMMON VEHICLE SYSTEM \\ WITH UNMANNED CRUISING SYSTEM
}

\author{
谷本 圭志 $^{1} \cdot$ 川村 周平 $^{2}$

\begin{abstract}
${ }^{2}$ 鳥取大学大学院博士前期課程＼cjkstart社会基盤工学専攻（E-mail: m08t7008b@edu.tottori-u.ac.jp)
\end{abstract} \\ ${ }^{1}$ 博士（工学）鳥取大学大学院准教授 社会基盤工学専攻 (E-mail: tanimoto@sse.tottori-u.ac.jp )
}

\begin{abstract}
無人で車両が走行する技術が確立されれば，車両を共同利用することによって様々な人々の移動の機会 を確保しうるシステムを構築しうる. しかし, このようなシステムの実現を検討するためには, その導入 が社会にどれだけの影響を与えるのかの把握が必要である.そのための基礎情報を得ることを目的として, 本研究では資源・エネルギーという環境的な側面に焦点を当て, システムのもとで所与のトリップ需要に 対してどれだけの資源，すなわち車両の投入が必要か，また，車両の走行にどれだけのエネルギーを要す るかについて定量的に評価するモデルを数理計画法を用いて構築する. その上で，ある地区を対象にいく つかのモデルを想定して実証的に検討する.
\end{abstract}

\section{キーワード : 無人運転技術, 車両共有システム, 割り当て問題}

\section{1. はじめに}

交通システムの技術開発が着実に進展している. 遠く ない将来において，現在とは異なった自動車の利用環境 が出現し,新たな車社会が実現する可能性は少なくない. その可能性を広げる有望な技術の一つとして, 自動車の 無人運転技術がある.

この技術と自動車との遠隔通信技術を組み合わせる ことで，地域に存在する車両の活用が容易となる．例え ば，現在では，通勤等の目的で利用された車両は，職場 や駅·空港などの様々な場所の駐車場で遊休しているが, 上記の技術を用いて車両を管理するシステムを構築・運 用寸ることで，運転手がいなくてもそれらの車両を無人 のタクシーのように活用することができるようになる.

このような車社会が実現すれば，上記のように活用され る自動車は, 世帯が独占する財ではなく, 地域社会が共 有する財との位置づけになろう。

無人運転技術を用いて上記のような車両の共有シス テム (以後, このシステムを単に「システム」と略す) が導入されれば, 車を運転できない人々であっても車で の移動が可能となる. その一方で, 社会に対する副次的 な影響も想定されるため，このようなシステムの実現に 向けて技術の進展を目指寸のかを議論をしていくために は，その導入が社会にどれだけの影響を与えるのかにつ いて様々な観点からの検討が必要である.

そのための基礎的な情報として, 本研究では, システ
ムが資源・エネルギーという環境面に及ぼす影響に焦点 を当て, それを評価するモデルを構筑する. 具体的には, システムが導入されたもとで, 所与のトリップ需要に対 してどれだけの資源，すなわち，車両の投入が必要か, また，システムの運用にどれだけのエネルギーを要する かという二点に着目し，それらを定量的に評価するモデ ルを数理計画法を用いて構築する. その上で, 鳥取県の ある地区を対象にいくつかのモデルを想定して実証的に 検討する.

\section{2. 本研究の基本的な考え方}

\section{1. 技術開発の動向}

運転を自動化するための技術は, 1939 年にニューヨー ク世界博において, ゼネラルモーターズ(GM)からの提案 が最初である. ただし，あくまで夢として示されたもの であり, 技術的な裏づけはなされていなかった. その後, 関連技術の進展とともに研究が進み, ハンドル操作の自 動化から前車への追従走行や, 磁気マーカーなどを用い た自動運転システムへと発展し, 1990 年代後半には専用 コースや未供用の高速道路などを用いた大規模な実験が 実施されるようになった ${ }^{1)}$.

日本では, 1991 年より旧運輸省による ASV (Advanced Safety Vehicle: 先進安全自動車) 推進計画が開始された. 国土交通省による 2006 年〜2010 年の第 4 期では，一部 
の要素技術ではあるが市販車両での実用化を目指してい る ${ }^{2)}$. わが国における自動運転の実用化の例としては, 専用道路上ではあるが，2005 年に愛知県で開催された 愛・地球博の IMTS (Intelligent Multimode Transit System) があり, 道路上に埋め込んだ磁気マーカーを用いて $\pm 10 \mathrm{~cm}$ の精度でバスの自動運転を行った ${ }^{3)}$.

地上のインフラに依存しない自動運転システムとして は，米国 DARPA（国防高等研究計画局）が開催した DARPA・グランドチャレンジがよく知られている. 2004 年および2005年は砂漠で実施され, 自律自動走行が可能 であることが技術的に示された. その後，2007 年には， 市街地をコースとする DARPA アーバンチャレンジが開 催され, 総延長 $96 \mathrm{~km}$ のコースを平均時速 $22 \mathrm{~km}$ で完走

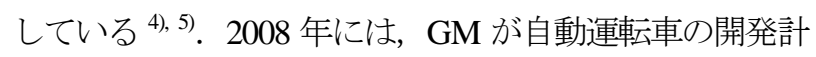
画を発表し, それによると 2015 年までに技術を完成させ， 2018 年には市場に投入するとしている5).

\section{2. 社会問題の解決の可能性}

運転の自動化技術の開発によって様々な社会問題の解 決が期待されている. 交通事故や交通渋滞の解決が期待 されてきたことは言うまでもないが，現在においては， 経済産業省の「エネルギーITS」6)に見られるように, 環 境対策としても注目されている.

この技術には，様々な主体が様々な観点から期待をし ていると考えられるが, 本研究で着目している車両の共 有化を想定すれば，上記にとどまらない大きな社会的な 貢献が期待できる. すなわち，運転手になれない人々に も移動の機会を確保することが可能になる．この点は, 現行の様々なシステムが抱える限界を克服することが可 能となる. 例えば, カーシェアリング 7), 8) は車両を共有 するという点では本研究で想定しているシステムとの共 通性を有しており, 本システムの代替案と一見考えられ るシステムであるが，このシステムはそもそも運転でき る人を対象として車両を共有するシステムであり, 運転 手になれない人への移動機会の確保は不可能である.ま た, 公共交通システムはそのような人々に移動機会を確 保するという点で本システムとの共通性を有するが, 路 線やダイヤが限定されるといった利便性の問題やとりわ け地方で生じているように公共交通システム自体が衰退 しているという事実がある.

以上のように，人々への移動の機会の確保という観点 において，無人運転技術を活用した車両の共有システム には大きな貢献が期待できる. しかしその一方で，本シ ステムが環境に与える影響については必ずしも肯定的で はない!すなわち，ある人の移動に用いられた車両はそ の用を終えると他の人の移動需要を満たすために無人で 回送される. 回送が生じる分, 走行に要するエネルギー は現在よりも増加する.また，現在公共交通を利用して
いる人々が本システムに転換したりトリップ需要そのも のが増加すればシステムの運用に必要な車両の数が減る とは限らず，現在よりも多くの資源を投入して車両を生 産しなければならないかもしれない.このため, それら の影響を定量的に評価しうるモデルとそれを用いた分析 が必要となる。

\section{3. 本研究で想定する状況}

2.1 で述べたように，2018年に自動運転車を市場に投 入する予定とのことではあるが，本システムの実現には 遠隔通信技術との統合や運用のための制度的・技術的な 検討などが必要であることから，システムの導入は少な くても今から 20〜30 年後となろう. その頃には, 人口減 少に伴い，都市域が（コンパクトシティのように意図的 かどうかは別として）縮小するといったように，国土・ 都市構造が現在とは異なる可能性があり，また，それ以 外にも社会を取り巻く状況の変化には様々な可能性が考 えられる. しかし，技術の進展や地球環境の変化に代表 されるように不確定な要因も多く, 現時点においてその 社会を正確に想定することは本研究の手に余る. このた め, 現在での状況をベンチマークとしつつ, 感度分析的 な検討を行うことがむしろ有効であろう。本システムが 導入される社会の正確な想定は，その技術の供用の見通 しがたった時点で改めて検討すればよいと考える.

また, 実証分析では人口減少や高齢化が進む鳥取県に おけるある地域を取り上げるが，そこでの人口構成は他 の都市の 20〜30 年後の姿であるかもしれない.もちろん, 実証分析の対象地域と他の都市との地理的な条件は異な るものの, いたずらな将来予測をするよりは, 将来像の 候補となりうる実在する地域を対象とした分析も着目に 值すると考えられる.

以上のことから, 本研究では, 現在の都市構造および トリップ需要をベースに検討を行う。その際, トリップ 需要については感度分析を行い, 需要量の変化について の考察を行うことで現在とは異なりらる社会の状況下で の分析を断片的にではあるが試みる. また，20３0 年後 において，自動車交通が本システムに完全に移行するか は定かではないが, 以下では, システムの環境影響を過 小に評価することを避けるために完全に移行した状況の もとで検討を行う. なお，システムをどのような主体が 運営するか, また，その動力源が何かなどに影響の度合 いは異なりうるが，システムが実用化段階にはない現在 においてそれらの想定を無理にすることは議論にかえつ て不利益が生じる. このため, 本研究では, それらの詳 細な設定はあえて行わない.その代わり, 環境への影響, すなわち, 資源量, 消費エネルギ一量と密接に相関する 指標である車両の必要台数および走行時間を算出する. そうすることにより，システムが実用化する時代の技術 
水準が何らかの形で与えられ，それに基づいて一台あた りの車両の生産に必要な資源量や走行時間あたりに要す るエネルギー量を見積もることができた段階で, 本研究 の結果にそれらを乗じることで資源量やエネルギ一量が 直ちに算出できるようになる.

\section{4. システムの概要と研究の方向性}

本システムは, 移動を必要とする人が事前にシステム の運営主体に予約を入れ, その予約に応じた移動サービ スを車両が無人で走行して供給するものであり，無人の タクシーサービスに近いイメージとなろう. なお, 運営 主体は，民間企業であっても自治体であっても構わず, 本研究ではそれを特定化しない.

車両を共有化するという点で, 本システムとカーシェ アリングは類似性を有するものの, 両者は同一ではない. カーシェアリングは現在既に供用が開始されているため, 当然のことながら, 現在の技術を前提として成立してい る. これに対し, 本研究では無人運転技術を前提として いるため, そのもとでの車両の運用はカーシェアリング でのそれとは異なる，具体的には，ある利用者のトリッ プを充足した後, 車両は別の利用者のもと一無人で回送 される点で大きく異なる. 現在では, 異なる人々が共同 で車を利用できるようにするために，車両の貸出返却場 所を予め決めておかなければならず, 例えば, Barth and Todd $^{9)}$, 島崎 ${ }^{10), 11), 12)}$, Nakayama et al. ${ }^{13)}$, 中山ら ${ }^{14)}$, 山本 ら ${ }^{15)}$ といった既往の研究ではその状況を想定している. しかし, 本システムのもとでは車両の貸出返却場所は不 要である. 車両の運用において本研究での想定とカーシ ェアリングのそれとは大きく異なるため, 本システムの 分析には別のモデル化が要請される.

また, カーシェアリングが現在供用されているという 状況にあることから，その研究も必然的に現在の法的, 経済的, 心理的な条件を与件として検討が蓄積されてい

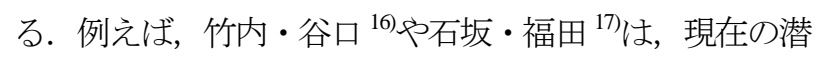
在的な利用者の料金への評価やシステムに対寸る意識な どを実証的に検討している．これに対して本システムは 幾分遠い将来時点における導入を想定していることから， これらの条件を与件とするのではなく,むしろ本システ ムの導入にはどのような社会的な影響があり, それを解 決するために上記の与件を含めてどのような付加的な改 善・修正を要するかについての議論の材料を提供するこ とに目的がある.この目的のもとでは, 現状をあえて与 件とはせず，本システムによる物理的な可能性を評価す るアプローチが求められるが，その視点に基づいた既存 研究は見当たらない.

そこで本研究では, 現在のトリップ需要を本システム で充足するという想定をべースとし, 最低限必要となる 車両台数および走行時間を定量的に評価するモデルをグ

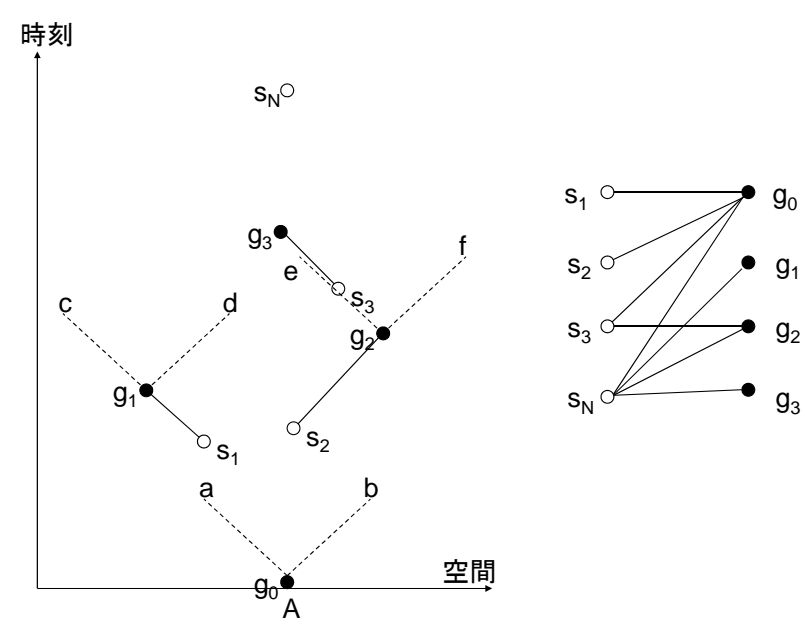

Fig. 1 時空間パスと二部グラフとの対応関係

ラフ理論におけるマッチング問題, 割り当て問題を援用 して構築する. また, そのモデルを用いてシステムの有 効性を実証的に確認する. なお, 2.2 で述べたように, 運 転手になれない人々にも移動の機会を確保するという点 で，本システムと他のそれとの代替は困難である．この ため, 本システムとその代替案との比較ではなく, 現状 との比較において有效性を確認するアプローチに基づく.

\section{3. モデル化}

\section{1. 車両の割り当てとマッチング問題}

所与のトリップ需要を満たすために最低限必要となる 車両台数や走行時間を評価するためには, トリップ需要 に対する車両の割り当てを導出寸るモデルが必要である. そのモデルとして,グラフ理論におけるマッチング問題, 割り当て問題が有用である. それらの考え方と車両の割 り当ての関係を時間地理学における時空間パスを用いて 説明する.

Fig.1には, 左側に時空間パス, 右側にそのパスに対応 したグラフを例示している. なお，ここでは議論の単純 化のため, 車両が走行する空間は西から東にといったよ うに一次元に広がっているものとする. 時空間パスはト リップの時空間的な軌跡を表すもので, 縦軸を時刻, 横 軸を空間とする座標平面内に記される. Fig.1 における 3 つの実線が時空間パスである. なお, 縦軸は, 原点に近 いほど早い時刻である. 横軸は, 原点に近いほど空間の 端（例えば対象地域における最も西側の地点）に近いこ とを示している.

図中の○， ○印のノードはそれぞれ人々が移動する際 の起点, 終点であり, それぞれを起点, 終点ノードと呼 ぶ. なお, それらは車両を回送する際の終点, 起点でも ある. 起点ノードと終点ノードの間に結ばれている実線 がトリップ需要である. 任意のノードの番号を $n$, 起点, 
終点ノードをそれぞれ $s_{n}, g_{n}$ で表すと, 任意のトリップは $\left(s_{n}, g_{n}\right)$ で表すことができる. Fig.1 では $\left(s_{1}, g_{1}\right),\left(s_{2}, g_{2}\right),\left(s_{3}, g_{3}\right)$ の3つのトリップ需要があることになり, それぞれが一 つの時空間パスと対応する．一台の車両が車庫に相当す る地点 A にあるとすると, このことは地点 A に $g_{0}$ とい うノードがあることで表現される. なお，この車両は， この日の終わりには地点Aにもどらなければないとする

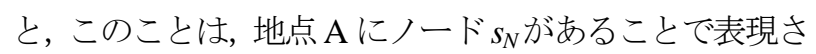
れる.

車両の走行速度には上限があるため, ある時間内に到 達可能な空間の範囲は限定される. 所与の走行速度のも とで $g_{0}$ から到達可能な空間の範囲は， $g_{0}$ と a, b を結ぶ 点線およびその延長の内部で示される.

車両をノード $g_{0}$ から $s_{1}$ に回送させ, トリップ需要 $\left(s_{1}, g_{1}\right)$ を充足するとする. このとき，車両はノード $g_{1}$ において 遊休する. $g_{1}$ から到達可能な空間の範囲に起点ノードは $S_{N}$ を除いて一つもないことから, 遊休した車両はノード $s_{N}$ に向からより他ない. これは，車両が車庫にもどるこ とを意味する. 一方で, 車両をノード $g_{0}$ から $s_{2}$ に回送さ せ，トリップ需要 $\left(s_{2}, g_{2}\right)$ を充足するとする. このとき， 車両はノード $g_{2}$ において遊休する. 上述と同様の議論に より, $g_{2}$ と e, f を結ぶ点線およびその延長の内部に $s_{1}$,が ないためノード $g_{2}$ からノード $s_{1}$ へは到達不可能であり， トリップ需要 $\left(s_{1}, g_{1}\right)$ に遊休した車両を充てることはでき ない. しかし，ノード $g_{2}$ からノード $s_{3}$ には到達可能であ るため，ノード $g_{2}$ において遊休した車両を回送させてト リップ需要 $\left(s_{3}, g_{3}\right)$ を満たしうる.

以上より，1 台の車両では 3 つのトリップ需要を満た すことができない. 一方，容易に推測されるように， 2 台の車両があればすべてのトリップ需要を満たすことが できる.

以上に示した状況やそのもとでの車両の割り当ての検 討は，グラフを用いて解析できる. Fig.1 の左側に記され ている時空間パスは, Fig.1の右側に記されているグラフ で表すことができる.このグラフは, 左側に起点ノード, 右側に終点ノードから構成されるグラフであり，二部グ ラフと呼ばれる. グラフに記されているリンクは実行可 能なリンクと呼ばれ，それで結ばれるノード間は到達可 能である. すなわち, 任意の二つのノードの間に実行可 能なリンクがあれば，当該のノード間に車両が回送でき ることを表している．例えば，ノード $g_{2}$ からは $s_{3}, s_{N}$ へ の実行可能なリンクがあるが，これはノード $g_{2}$ で遊休し た車両をノード $s_{3}, s_{N}$ に回送できることを表している（も し， $s_{N}$ に回送した場合，ノード $s_{3}$ を起点とするトリップ 需要は満たさないことになる). 一方で, 実行可能なリン クで結ばれていないノード間に車両は回送できない.

どのトリップ需要にどの車両を割り当てるかは，実行 可能なリンクのうちどのリンクに実際に車両を回送させ
るかと同じ問題である. ここに, 少なくても何台の車両 があれば（つまり，Fig. 1 においてはノード $g_{0}$ の位置に 起点ノードが何個あれば) すべてのトリップ需要を満た すことができるかという問題として定式化すれば，す心゙ てのトリップ需要を満たすための車両の必要台数を求め るモデルとなる. 一方, リンクに車両を回送させる際の コストを与え, すべてのトリップ需要を満たすための最 小のコストを求める問題として定式化すれば，コストを 最小化するモデルを導きうる. そのコストを走行時間で 与えれば, コスト最小化は走行時間最小化の問題となる.

上記のそれぞれのモデルは数理計画におけるマッチン グ問題, 割り当て問題に属する. したがって, 時空間パ スとして表されたトリップ需要を二部グラフ上における 問題に対応づけることで, マッチング問題, 割り当て問 題における知見や計算アルゴリズムをそのまま本研究の 車両の割り当て問題に援用することができる. なお，以 後の検討においては複数のトリップ需要を一つの車両で 充足することはないものとする. すなわち, 相乗りはな いものとする.

\section{2. 定式化}

任意の起点，終点ノードをそれぞれ $i, j$ で表す．実行 可能なリンクの集合を $L$ で表し, その任意の要素を $(i j) \in L$ で表す.リンク $(i j)$ に車両を回送させるか否かを表す変数 $x_{i j}$ を以下のように定義する.

$$
x_{i j}=\left\{\begin{array}{cc}
1 & ((i j) \text { に回送させる場合 }) \\
0 & \text { (その他の場合 })
\end{array}\right.
$$

また，リンクのコスト $c_{i j}{ }^{*}$ を次式のように定義する.

$$
c_{i j}^{*}= \begin{cases}c_{i j} & ((i j) \in L \text { の場合 }) \\ M & (\text { その他の場合 })\end{cases}
$$

ここに， $c_{i j}$ はリンク $(i j) に$ 車両が回送した際のコストで ある. 車両の台数を最小化するモデルにおいては起点ノ ード $i$ が車両の車庫 (Fig.1 における $g_{0}$ の位置に存在する ノード）である場合に 1 ，そうでない場合に 0 のコスト が与えられる. また，走行時間を最小化するモデルにお

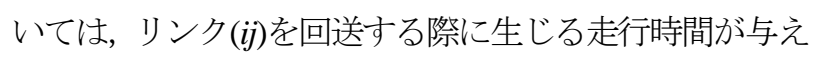
られる. $M$ は禁止的に大きな数值であり, 実行不可能な リンクに車両が回送されることがないようにするための 技術的工夫である. 寸ると, 車両の割り当て問題は次式 のように定式化できる. 
Table 1 目的別トリップ原単位（上/下段 : 男性/女性）

\begin{tabular}{|c|c|c|c|c|c|c|c|}
\hline $\begin{array}{c}\text { 目 } \\
\text { 的 }\end{array}$ & 10 代 & 20 代 & 30 代 & 40 代 & 50 代 & 60 代 & $\begin{array}{c}70 \text { 代 } \\
\text { 以上 }\end{array}$ \\
\hline 通 & 0.458 & 0.789 & 0.872 & 0.832 & 0.814 & 0.546 & 0.272 \\
勤 & 0.615 & 0.614 & 0.595 & 0.615 & 0.609 & 0.265 & 0.450 \\
\hline 通 & 0.208 & 0.040 & 0.000 & 0.000 & 0.000 & 0.000 & 0.000 \\
学 & 0.154 & 0.059 & 0.000 & 0.002 & 0.003 & 0.000 & 0.000 \\
\hline 買 & 0.083 & 0.033 & 0.050 & 0.048 & 0.061 & 0.156 & 0.218 \\
物 & 0.038 & 0.230 & 0.250 & 0.356 & 0.320 & 0.291 & 0.050 \\
\hline 通 & 0.000 & 0.008 & 0.008 & 0.011 & 0.021 & 0.077 & 0.128 \\
院 & 0.077 & 0.032 & 0.034 & 0.046 & 0.038 & 0.103 & 0.200 \\
\hline \multirow{2}{*}{ A } & 0.009 & 0.009 & 0.030 & 0.041 & 0.041 & 0.027 & 0.093 \\
& 0.000 & 0.000 & 0.113 & 0.080 & 0.080 & 0.077 & 0.093 \\
\hline \multirow{2}{*}{ B } & 0.010 & 0.010 & 0.043 & 0.011 & 0.011 & 0.041 & 0.024 \\
& 0.000 & 0.060 & 0.060 & 0.074 & 0.074 & 0.019 & 0.005 \\
\hline \multirow{2}{*}{ C } & 0.003 & 0.003 & 0.011 & 0.004 & 0.004 & 0.010 & 0.034 \\
& 0.004 & 0.004 & 0.025 & 0.012 & 0.012 & 0.003 & 0.033 \\
\hline \multirow{2}{*}{$\mathrm{D}$} & 0.027 & 0.027 & 0.018 & 0.024 & 0.024 & 0.024 & 0.041 \\
& 0.033 & 0.033 & 0.083 & 0.046 & 0.046 & 0.057 & 0.011 \\
\hline \multirow{2}{*}{$\mathrm{E}$} & 0.031 & 0.031 & 0.025 & 0.024 & 0.024 & 0.022 & 0.025 \\
& 0.032 & 0.032 & 0.034 & 0.029 & 0.029 & 0.028 & 0.006 \\
\hline \multirow{2}{*}{$\mathrm{F}$} & 0.026 & 0.026 & 0.057 & 0.037 & 0.037 & 0.023 & 0.040 \\
& 0.052 & 0.052 & 0.039 & 0.028 & 0.028 & 0.025 & 0.022 \\
\hline \multirow{2}{*}{$\mathrm{G}$} & 0.024 & 0.024 & 0.014 & 0.032 & 0.032 & 0.023 & 0.009 \\
& 0.022 & 0.022 & 0.018 & 0.017 & 0.017 & 0.012 & 0.000 \\
\hline \multirow{2}{*}{$\mathrm{H}$} & 0.013 & 0.013 & 0.008 & 0.014 & 0.014 & 0.010 & 0.024 \\
& 0.002 & 0.002 & 0.010 & 0.015 & 0.015 & 0.017 & 0.020 \\
\hline 人 & 136 & 255 & 328 & 247 & 401 & 229 & 144 \\
口 & 133 & 265 & 383 & 260 & 397 & 250 & 196 \\
\hline & & 単位 & 原単位 : トリップ数/日, 人口 1 人 \\
\hline
\end{tabular}

※目的 A〜H は Table 2 を参照

Table 2 比較的小さな需要規模のトリップ目的の種類

\begin{tabular}{ll}
\hline $\mathrm{A}$ & $\begin{array}{l}\text { 各種会合やイベント(週末や夏休みの学習講座や公民 } \\
\text { 館での集いなど)への送迎 }\end{array}$ \\
\hline $\mathrm{B}$ & 雨や雪の日に家族の送迎をする \\
\hline $\mathrm{C}$ & 病院への搬送(例:急病の子供を小览科に連れていく) \\
\hline $\mathrm{D}$ & 銀行, 郵便局, 市役所での用事 \\
\hline $\mathrm{E}$ & 美容院や理髪占 \\
\hline $\mathrm{F}$ & 本屋・レンタルビデオショップヘ行く \\
\hline $\mathrm{G}$ & 急な買い物で夜や早朝にスーパーやコンビニなどに \\
& 行く \\
\hline $\mathrm{H}$ & 灯油を買いに行く \\
\hline
\end{tabular}

$$
\sum_{i} \sum_{j} c_{i j}^{*} x_{i j} \rightarrow \min
$$

$$
\begin{aligned}
& \sum_{j} x_{i j} \geq 1 \quad(\forall i) \\
& \sum_{i} x_{i j} \leq 1 \quad(\forall j)
\end{aligned}
$$

ここに, 式(3)はトリップ需要の充足条件を, 式(4)は車 両の配車制約（1 台で複数の需要を充足できない）を表 している. この問題の数值的解法としてはハンガリーの アルゴリズムが提案されている ${ }^{18)}$.

\section{4. 事例分析}

\section{1. 対象地域および計算の想定}

鳥取県のある地区にシステムを導入した場合を想定し， 必要となる車両の台数, 走行時間を最小化するモデルを それぞれ計算する．なお，いかなる車両の割り当てにお いてもすべてのトリップ需要を満たすことを前提として いるため, 最小化の対象となる走行時間は実質的には回 送時間である. このため, 以後では，走行時間最小化と 回送時間最小化は区別なく用いる.

パーソントリップ調査および当該地区へのアンケート 調査結果により平日一日あたりのトリップ需要の原単位 をTable 1, 2のように与えた. パーソントリップ調査に当 該の地区のデータがなかったため，鳥取県内の別の都市 のデータで代用した. パーソントリップ調査からは, 通 勤, 通学, 買い物, 通院といった比較的大きな需要規模 のトリップ目的, アンケート調査からは,「各種会合やイ ベント (週末や夏休みの学習講座や公民館での集いなど) への送迎」「雨や雪の日に家族の送迎をする」「病院への 搬送（例 : 急病の子供を小児科に連れていく）」「銀行, 郵便局，市役所での用事」「美容院や理髪占」「本屋・レ ンタルビデオショップヘ行く」「急な買い物で夜や早朝に スーパーやコンビニなどに行く」「灯油を買いに行く」と いった比較的小さな需要規模のトリップ目的の原単位を 得た.これらについては, データの制約上, 10代と20代, 40代と50代の原単位は等しいものとして算出した. トリ ップの発生時間や目的地の分布についてもこのアンケー 卜調査に基づいて設定した. 次いで，これらの原単位に 当該地区の人口規模を乗じ，トリップ需要を想定した. 人口規模をTable $1 の$ 最下行に記す.

この地区は，通勤・通学は概ね $10 \mathrm{~km}$ 圈内，買い物は $5 \mathrm{~km}$ 圈内であり, 道路に大きな渋滞は発生しない. また, この地区から 10 分圈内に大学や空港, 病院があることか ら，そのゾーンに車両の車庫があることを想定した。 ま 
た, 車両は出庫した後にトリップ需要を充足するが, 深 夜には車庫に必ず帰還するものとした.

一日当たりの人々の総トリップ数は 7,594 トリップで ある. なお，現在においてはそれを 2,832 台でまかなっ ており，回送時間は当然のことながら 0 分であるが，実 車の走行時間は 227,302 分である.

\section{2. 計算結果と考察}

それぞれのモデルの計算結果をTable 3に示寸. なお, いずれのモデルにも複数の解がありうるため, 例えば必 要台数を最小化する場合には, 必要台数の最小值を求め た上で，その值を所与として回送時間最小化のモデルを 下位問題として求めた. 回送時間を最小化する場合につ いても同様の考え方に基づいた.

必要台数最小化の計算結果より, 少なくても1,174台の 車両があれば7,594トリップを充足しうることが明らか となった. 現在においては2,832台でトリップ需要を満た していることから，それと比べて半数以下の台数があれ ば十分で対応できることが明らかになった.1台当たりの トリップ充足数では6.47トリップ／台であり, 台数を抑 えた運用を行えば1台で多くのトリップを満たしうると 言える. ただし, 必要台数最小化のもとでの 1 台あたりの 回送時間は, 回送時間最小化のそれと比べて2倍以上とな っている. これは, 必要台数最小化では少ない台数で所 与のトリップ需要を満たさなくてはならないため, 車両 の回転を高めているためである.このことは, 回送最小 化における1台当たりのトリップ数が必要台数最小化の それと比べて $1 / 2$ 程度となっていることからも裏付けら れる.

消費エネルギーについては回送時間が少ないほど望ま しく, この時間がどの程度のエネルギー消費量に対応す るのかについてはシステムが導入される時点でのエネル ギー効率に依存する. ただし, 現在における車両の走行 時間が227,302分であるのに対して, システムの導入時に おけるそれ（導入時においては回送が生じるため, 実車 と回送時間の合計）は少なくても311,986分（回送時間最 小化における回送時間を実車の走行時間に加えた值）で あり，1.37倍の走行時間となっている. このため, 走行 時間の増分を相殺するほどのエネルギー効率を達成して いなければ, 環境負荷は増大寸るということが示される。 逆に, システムの導入に伴う負荷を増大させないために は，1.37倍の走行時間の増加を相殺するエネルギー効率 の改善技術が必要である.

実車, 空車台数の数を時系列で整理したのが Fig.2 で ある.この図から, 回送時間最小化においては朝の通勤・ 通学ピークの後のしばらくの間, 車庫からの車両の供給 が急増していることが分かる. これは, 必要台数最小化 においては出庫する台数を最小化するために通勤・通学
Table 3 計算結果

\begin{tabular}{|l|c|c|}
\hline モデル & $\begin{array}{c}\text { 回送時間 } \\
\text { 最小化 }\end{array}$ & $\begin{array}{c}\text { 必要台数 } \\
\text { 最小化 }\end{array}$ \\
\hline 必要台数 (台) & 2,054 & 1,174 \\
\hline 回送時間 (分) & 84,684 & 106,318 \\
\hline $\begin{array}{l}1 \text { 台当たりの回送時間 } \\
\text { (分/台) }\end{array}$ & 41.23 & 90.56 \\
\hline $\begin{array}{l}1 \text { 台当たりのトリップ } \\
\text { 充足数 (トリップ/台) }\end{array}$ & 3.70 & 6.47 \\
\hline $\begin{array}{l}1 \text { トリップ当たりの回 } \\
\text { 送時間 (分/トリップ) }\end{array}$ & 11.15 & 14.00 \\
\hline
\end{tabular}

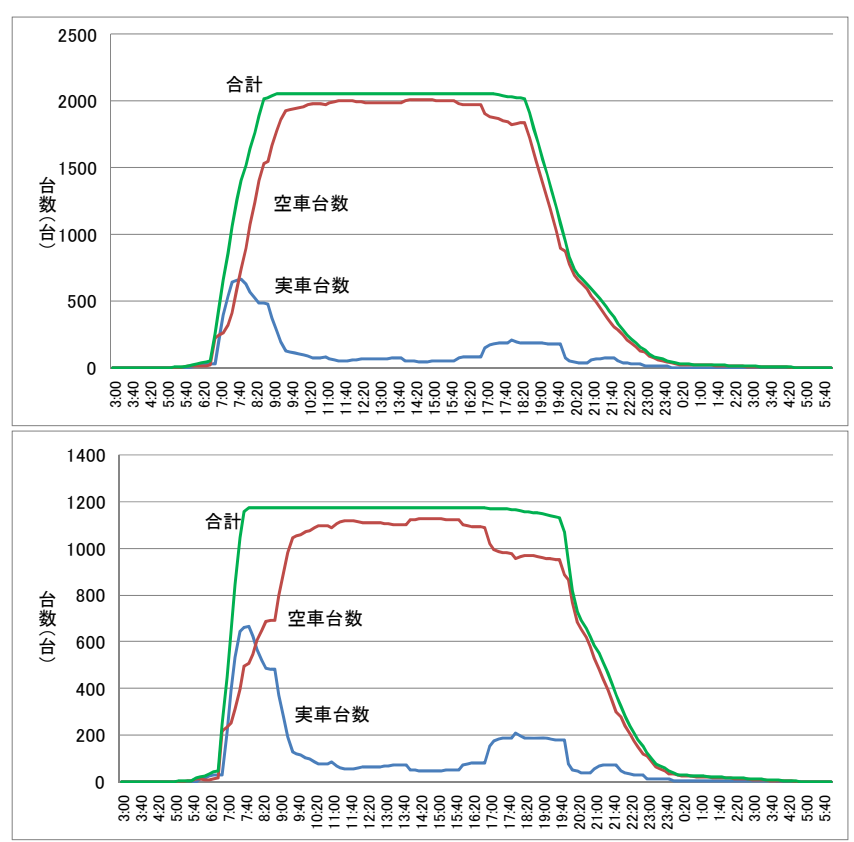

Fig. 2 実車, 空車台数の時系列変化

(上/下段:回送時間最小化, 必要台数最小化)

のトリップ需要を充足した後にその車両を他の目的の充 足のために回送するのに対し，回送時間最小化において は, 回送時間を抑えるために台数の供給を増やすという 運用が行われるためである.

\section{3. 感度分析}

本システムを導入した場合にはシステムそのものが交 通行動に大きな変化をもたらすことが考えられ，トリッ プ原単位も現在のそれとは異なる可能性がある. そこで 以下では, トリップの原単位を変化させて感度分析を行 う. その際, 通勤や通学, 通院といった必須的な社会的 活動のトリップよりは買い物のように選択的な活動の方 がより大きな影響を受ける可能性があると考えられるた め, 買い物を対象として, その原単位を現在の1.5, 2.0倍 とした場合について感度分析を行う. トリップ原単位を 
Table 4 計算結果（買い物目的のトリップ原単位 1.5 倍）

\begin{tabular}{|l|c|c|}
\hline モデル & $\begin{array}{c}\text { 回送時間 } \\
\text { 最小化 }\end{array}$ & $\begin{array}{c}\text { 必要台数 } \\
\text { 最小化 }\end{array}$ \\
\hline 必要台数 (台) & 2,075 & 1,174 \\
\hline 回送時間（分） & 87,012 & 109,066 \\
\hline $\begin{array}{l}1 \text { 台当たりの回送時間 } \\
\text { (分／台 })\end{array}$ & 41.93 & 92.90 \\
\hline $\begin{array}{l}1 \text { 台当たりのトリップ } \\
\text { 充足数 (トリップ／台) }\end{array}$ & 3.95 & 6.90 \\
\hline $\begin{array}{l}1 \text { トリップ当たりの回 } \\
\text { 送時間 (分／トリップ }\end{array}$ & 10.60 & 13.29 \\
\hline
\end{tabular}
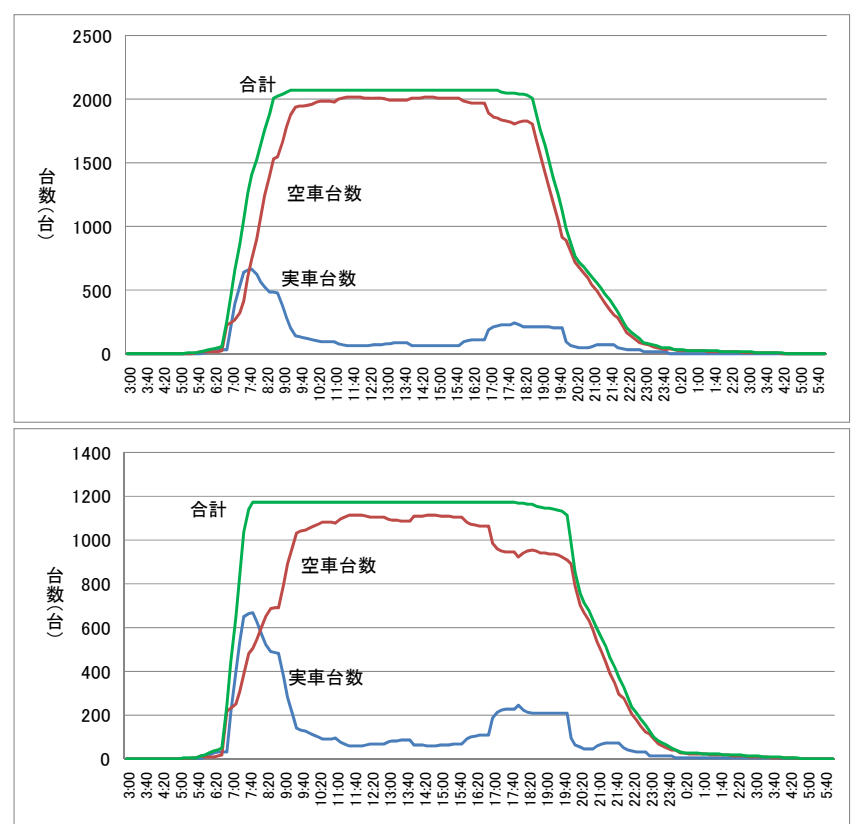

Fig. 3 買い物目的のトリップ原単位を1.5倍した場合の 実車, 空車台数の時系列変化

(上/下段 : 回送時間最小化, 必要台数最小化)

現在の1.5, 2.0倍とした場合の総トリップ数はそれぞれ 8,206, 8,752トリップである (現在のトリップ原単位のも とでは7,594トリップである). その結果, Table 4, 5およ びFig.3, 4を得た.

これらによると, トリップ原単位が増えても, 必要台 数最小化においては車両の台数がまったく変化しないこ とが分かる. 回送時間最小化においても車両の台数は増 えるもののその増加分はわずかである. これは, 必要台 数は朝の通勤・通学のピーク時のトリップ需要でほぼ決 定されており，それ以降の時間帯についてはピーク時に 車庫を発った車両を運用寸ればトリップ需要が充足可能 であるためと考えられる. 実際, 買い物トリップが倍増 しても通勤のトリップ原単位にはまったく及ばないこと はTable 1から確認できる.
Table 5 計算結果（買い物目的のトリップ原単位 2.0 倍）

\begin{tabular}{|l|c|c|}
\hline モデル & $\begin{array}{c}\text { 回送時間 } \\
\text { 最小化 }\end{array}$ & $\begin{array}{c}\text { 必要台数 } \\
\text { 最小化 }\end{array}$ \\
\hline 必要台数（台） & 2,096 & 1,174 \\
\hline 回送時間 (分) & 90,036 & 112,540 \\
\hline $\begin{array}{l}1 \text { 台当たりの回送時間 } \\
\text { (分/台) }\end{array}$ & 42.96 & 95.86 \\
\hline $\begin{array}{l}1 \text { 台当たりのトリップ } \\
\text { 充足数 (トリップ／台) }\end{array}$ & 4.18 & 7.45 \\
\hline $\begin{array}{l}1 \text { トリップ当たりの回 } \\
\text { 送時間 (分/トリップ) }\end{array}$ & 10.29 & 12.86 \\
\hline
\end{tabular}

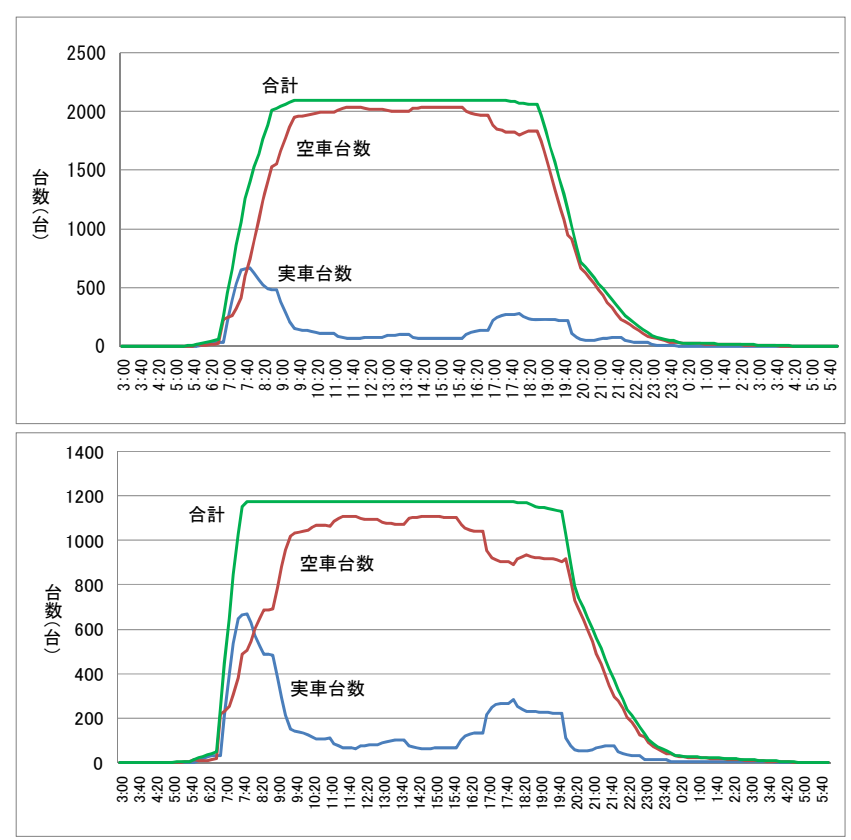

Fig. 4 買い物目的のトリップ原単位を2.0倍した場合の 実車, 空車台数の時系列変化

(上/下段: 回送時間最小化, 必要台数最小化)

回送時間最小化においては，トリップ原単位が増えて も, その増加分に比べて回送時間の増加はわずかである. 実際, 買い物目的のトリップ原単位を1.5, 2.0倍としても 回送時間は1.03, 1.06倍になるだけである.

車庫を発った車両は, 朝のピーク以降の時間帯に（買 、物のトリップ原単位が1.0倍である場合と比べて）より 多くの需要を充足するよう運用がなされるため, 1 台当た りの回送時間は増え, また, 1台当たりのトリップ充足数 も増える. このことは, 必要台数最小化, 回送時間最小 化に共通した傾向である. ただし, 1 トリップ当たりの回 送時間は原単位が増えると減少する結果となった．この ことは, トリップ数の増加に比べて回送時間の増加が少 ないことと等価である.この原因については以下のよう に考えられる. 先述のように, 朝の通勤・通学の需要に 
対応するために出庫した車両の台数は日中の需要を満た すのに十分である. このため, 日中の買い物のトリップ 数が増えても追加的な車両を多く出庫させる必要はなく, 遊休状態となっている車両で買い物の需要を満たすこと ができる. また，今回の計算における地理的な条件によ り, 車庫から車両を回送させる時間に比べてトリップ需 要を充足して遊休している車両を回送させる方が短い場 合が多く，回送時間を最小化するという意味においても 買い物の需要の増加に対して追加的な車両を多く出庫さ せることは有利ではない. 以上より, 1トリップ当たりの 回送時間は原単位が増えると減少する結果になったと考 えられる.

Fig.3, 4には, 感度分析における実車, 空車台数の時系 列変化を示しているが, Fig.2と比べて大きな定性的な変 化は見られない. すなわち, 買い物目的のトリップ原単 位が増えても，一日における実車，空車台数の時系列変 化には質的な変化は生じないものと考えられる.

以上より, 通勤・通学の需要量やそのパターンが現在 と変わらなければ，多少のトリップの増加に対するシス テムの環境影響はほとんど変わらない. なお,この結果 は，朝に通勤・通学のトリップ需要が大量に発生してい るという検討地区の特徵によるためである. その特徵を 有していない地区においては，時系列変化に質的な変化 が生じる可能性があることに留意を要するものの，多く の都市において見られる特徵であるのも事実である.

通勤・通学で用いられた車両でその後の時刻に発生す る様々な活動に割り当てていくという姿が分析によって 明らかになったことを踏まえると, 通勤・通学活動の時 空間的な分布やトリップ需要量が本システムの環境負荷 の支配的な要因と考えられる.このことから，本システ ムの環境影響を小さくするには，エネルギ一効率だけで はなく, 都市もシステムに適合した構造にすることが有 効となる. 具体的には, 人々の移動の範囲が小さい, 通 勤・通学先と居住地が近いといった構造が適していると 考えられる. ただし, 後者については, いわゆる職住近 接ということではなく, ある人の通勤・通学目的地の周 辺に別の人の居住地があるというように，ある人がトリ ップを終える場所が他の人にとってトリップを始める場 所であるということに留意を要する.より一般的には, 通勤・通学の目的地がある場所を起点として回送が少な くなるよう外出目的地と居住地が順次配列されている都 市構造が望ましいということになろう.

\section{5. おわりに}

本研究では, 無人運転技術を用いた車両の共有システ ムが導入されたもとで，システムの運用に際して資源の
投入量および消費エネルギー量といつた環境影響がどれ ほど生じるのかという二点に着目し，それらを定量的に 評価するモデルを数理計画法を用いて検討した. 具体的 には, グラフ理論におけるマッチング問題, 割り当て問 題を援用して車両をトリップ需要に割り当てるモデルを 構築した. その上で，鳥取県のある地区を対象にいくつ かのモデルを想定して実証的に検討し, 現在と比べてど れだけの環境負荷の増減が生じるのかを明らかにした。

また，買い物を対象としてトリップ需要が現在のそれ よりも大きくなった場合について感度分析を行った. そ の結果，投入する資源や消費エネルギーに大きな変化が ないことを明らかにした. また, その結果を踏まえ, 通 勤・通学の需要量やパターンがシステムの環境負荷に対 して支配的であることを明らかにした。

ここでの計算結果はあくまで検討対象地区の都市構 造のもとでの結果であり, それぞれのモデルの計算結果 の差異は前提とする都市構造によって異なりうる. しか し，本システムに伴う環境負荷を減じるためには，本シ ステムの特徴である車両の回送がなるべく生じない都市 構造が有効であることは自明である. すなわち，ある人 がトリップを終える場所が他の人にとつてトリップを始 める場所となるような構造である. 現在の都市構造は, 車両が回送されることを想定して形成されているわけで はないことから，上記の構造が現在備わっているとは考 えにくい. 具体的に本システムのもとでどのような構造 が望ましいのかは，今後の検討を要する事項である.

また，今回の計算は車庫が一箇所であるという想定で あったが，より広い地域を対象として検討する場合には その想定を変更する必要がある，例えば，域内に複数の 車庫があるという想定が求められる，また，公共交通シ ステムのように人々の乗りあいを認めることで移動の機 会を効率的に確保する可能性も考えられる. いずれにつ いても，モデルの定式化，計算方法等について拡張が必 要となる. この点についても, 今後の課題としたい.

本システムを実用化するには, 本研究で焦点を当てた 環境面に加えて様々な観点に基づいた社会的な影響の検 討が必要となる. その一つとして, 人々の生活パターン や交通行動の変化がある. 無人運転技術のもとでは, 人々 が移動して財やサービスを調達せずとも財やサービスを 移動させて調達することが可能になる. そうすると, 人々 は移動しないと調達できない場合のみに移動するという ことになるかもしれない. それに伴い，人々の間のつき あいのあり方やその変化に伴う副次的な問題が生じる可 能性もあり，交通に限定されない幅広い分野から構成さ れる学際的な研究が今後必要になると考えられる. 


\section{参考文献}

1) 津川定之 (2006)「自動車の運転技術の変遷」,『自動車技術』, Vol.60, No.10, pp.4-9.

2) 田路龍吾 (2006)「先進安全自動車 (ASV) 推進計画について -第 3 期の主な内容と第 4 期の概要-」, 『自動車技術』, Vol.60, No.12, pp.10-15.

3) 橘彰英, 田口康治 (2006)「実用に供された IMTS」, 『自動車 技術』, Vol.60, No.10, pp.29-33.

4) Buehler, M., Iagnemma, K. and Singh, S. (2007). "The 2005 DARPA Grand Challenge: The Great Robot Race”, Springer-Verlag.

5) 濱坂隆 (2008)「DARPA アーバンチャレンジ調查レポート」, 『自動車研究』, Vol.30, No.3, pp.29-32.

6) 日刊自動車新聞記事, 2008.1.13.

7) 交通工学 (2001)「交通社会における新しいクルマの使われ方 一共同保有・共同利用の取組み一」, Vol.36, No.2, pp.1-42.

8) 平石浩之, 中村文彦, 大蔵泉 (2005)「カーシェアリング社会 実験の現状と導入に向けた計画手法の課題」『土木学会論文 集』, No.786/IV-67, pp.3-10.

9) Barth, M. and Todd, M. (1999). "Simulation Model Performance Analysis of Multiple Station Shared Vehicle System”, Transportation Research Part C, Vol.7C, pp.237-259.

10) 島崎敏一 (2001)「車輛共同利用システムの車輛配備台数の 最適化」, 『土木計画学研究・講演集』, No.24 (2), pp.309-312.

11) 下原祥平, 島崎敏一 (2001)「車両共同利用システムにおけ る車両の最適配車」, 『土木計画学研究・講演集』, No.24 (2), pp.317-320,

12) 島崎敏一, 下原祥平 (2002)「車両共同利用の配車のシミュ レーションモデル」, 『土木計画学研究・講演集』, No.25,

\section{CD-ROM.}

13) Nakayama, S., Yamamoto, T. and Kitamura, R. (2002). “A Simulation Analysis for the Management of an Electric-Vehicle Sharing System: The Case of the Kyoto Public-car System”, Transportation Research Record 1791, pp.99-104.

14) 中山晶一朗, 山本俊行, 北村隆一 (2002)「再配車によらな い電気自動車の共同利用システムの効率化に関する研究」, 『土木計画学研究・論文集』, Vol.19, pp.481-487.

15) 山本俊行, 中山晶一朗, 北村隆一 (2005)「再配車を用いな い複数ステーション型自動車共同利用システムの挙動に関 するシミュレーション分析」, 『土木学会論文集』, No.786/IV -67, pp.11-20.

16) 竹内新一, 谷口栄一 (2005)「業務交通を対象としたカーシ エアリング実証実験」, 『土木学会論文集』, No.786/IV-67, pp.21-30.

17) 石坂哲宏, 福田敦 (2005)「大学キャンパスを中心とする電 動アシスト自転車による共同利用の取り組み」, 『土木学会論 文集』, No.786/IV-67, pp.31-38.

18) アラン・ドーラン, ジョーン・オールダス(2003)『よくわか るネットワークのアルゴリズム』(大石康彦訳) 日本評論社.

\section{謝辞}

本研究の遂行においては，構想から計算に至る様々な 面で (株) 豊田中央研究所の中野道王氏に貴重なアドバ イスをいただいた。 また，アンケートの配布に際しては 鳥取市末恒公民館館長に協力をいただいた．ここに感謝 の意を表します。

\title{
ENVIRONMENTAL IMPACT BY COMMON VEHICLE SYSTEM WITH UNMANNED CRUISING SYSTEM
}

\author{
Keishi TANIMOTO ${ }^{1}$, Syuhei KAWAMURA ${ }^{2}$ \\ ${ }^{1}$ Dr. of Eng., Associate Professor, Department of Social Systems Engineering, Tottori University \\ (E-mail: tanimoto@sse.tottori-u.ac.jp) \\ ${ }^{2}$ Department of Social Systems Engineering, Tottori University \\ (E-mail:m08t7008b@edu.tottori-u.ac.jp)
}

\begin{abstract}
When unmanned cruising technique of vehicles is developed, new transportation society will be emerged. Given this technique, it is possible to design new system in which vehicles are used as common resources in the society to meet the trip demand without the drivers by automatic controller. However, this system may increase environmental burden. This study constructs the model to evaluate the environmental impact such as energy consumption by mathematical programming methods. Then the model is applied to case study area in order to analyze how the impact is and discuss how the impact is mitigated.
\end{abstract}

Key Words: Unmanned cruising technique, common vehicle system, assignment problem 